Available online at Dakwah: Jurnal Kajian Dakwah dan Kemasyarakatan http://journal.uinjkt.ac.id/index.php/dakwah

Dakwah: Jurnal Kajian Dakwah dan Kemasyarakatan, 24 (1), 2020, 71-89

\title{
Revitalisasi Dakwah Islam: Toleransi, Harmonisasi, dan Moderasi
}

\author{
Syahirul Alim \\ syahirulalm@uinjkt.ac.id \\ Sekolah Pascasarjana UIN Syarif \\ Hidayatullah Jakarta
}

\begin{abstract}
Islamisation is sometimes interpreted as a religious mission to balance Christianisation which is closely related to the missionary aspects of religions. Islamisation or Islamic da'wah activities are tolerant, moderate and harmonious, taking into account humanitarian aspects in many ways. The long history of Islamisation throughout the world shows that Islam is a tolerant religion in which the process of religious conversion is carried out voluntarily and peacefully. Islamisation in the Archipelago is the best example of a successful da'wah activities in the conversion of Islam both individually and collectively. Muslim missionaries in the Archipelago are intellectual sufism figures who have the broad ability to revitalize da'wah into rational, reformist and progressive manner.
\end{abstract}

Keywords: revitalization, tolerance, harmonization, moderation

\begin{abstract}
Abstrak
Islamisasi terkadang dimaknai sebagai misi keagamaan untuk menyeimbangkan Kristenisasi yang erat kaitannya dengan aspek dakwah agama. Islamisasi atau kegiatan dakwah Islam bersifat toleran, moderat, dan harmonis dengan memperhatikan aspek kemanusiaan dalam banyak hal. Sejarah panjang Islamisasi di seluruh dunia menunjukkan bahwa Islam adalah agama yang toleran di mana proses perpindahan agama dilakukan secara sukarela dan damai. Islamisasi di Nusantara adalah contoh terbaik dari kegiatan dakwah yang berhasil dalam konversi Islam baik secara individu maupun kolektif. Misionaris Muslim di Nusantara adalah tokoh sufisme intelektual yang memiliki kemampuan luas untuk merevitalisasi dakwah ke arah rasional, reformis dan progresif.
\end{abstract}

Kata Kunci: revitalisasi, toleransi, harmonisasi, moderasi

Permalink/DOI: http://doi.org/10.15408/dakwahv24i1.17836

\section{Pendahuluan}

Islam merupakan agama yang penyebarannya relatif cepat, hanya kurang dari satu abad, wilayah kekuasaan Islam telah jauh melampaui Hijaz. Melalui semangat ekspansi politik yang telah dimulai sejak masa Nabi Muhammad, pasukan Muslim telah berhasil menundukkan wilayah kekuasaan Persia dan Bizantum.
Ekspansi Islam tidak dilakukan dengan cara-cara militeristik yang kejam, tidak pula didorong semangat religius untuk menyebarkan kebenaran ajarannya. Tujuan utama mereka tentu saja pragmatis: menginginkan harta rampasan dan melakukan kegiatan yang biasa mereka lakukan untuk mempertahankan kesatuan umat (Armstrong 2002, 36). 
Dalam kegiatan ekspansi, terselip misi dakwah yang berwatak toleran, berupaya menghindari konflik dalam bentuk apapun demi terbentuknya harmonisasi sosial. Aspek- aspek tradisi dan budaya yang telah hidup ditengah masyarakat seringkali dibiarkan, terkadang bahkan dilestarikan, sekalipun tampak seolah-olah saling bertentangan dengan ajaran Islam itu sendiri. Itulah sebabnya, di wilayah manapun Islamisasi terjadi, justru "resepsi" atau bahkan "akulturasi" yang tampak, sehingga Islam seringkali membentuk corak peradabannya tersendiri yang khas.

Aktivitas dakwah pada masa ekspansi seringkali tampak samar, sekalipun banyak wilayah-wilayah nonMuslim yang secara sukarela justru melakukan konversi terhadap Islam. Sikap toleransi yang sedemikian besar yang dibawa bersama semangat ekspansi, lebih banyak mempengaruhi cara pandang non-Muslim terhadap keindahan ajaran-ajaran Islam. Memang, beberapa ajakan kepada mereka yang masih ingkar dilakukan juga melalui surat-surat atau delegasi politik yang dikirim kepada para penguasa setempat, namun hampir tidak pernah bersifat paksaan tetapi lebih kepada pilihan, dengan tentu saja kesepakatankesepakatan tertentu dengan mempertimbangkan aspek-aspek kemanusiaan. Tidak heran, jika suatu masyarakat yang simpatik terhadap caracara yang dilakukan pasukan Muslim setelah pendudukan suatu wilayah, mereka berbondong-bondong masuk Islam dan berkomitmen untuk mempertahankan, menjaga, dan melestarikan ajaran-ajaran Islam.
Semangat dakwah dalam diri setiap Muslim tentu saja muncul sebagai aktivitas yang bertujuan memperteguh dan memperdalam aspek keimanan sekaligus membantu mereka menyesuaikan kehidupan sehari-hari mereka dengan prinsip-prinsip ajaran Islam (Meuleman 2011, 236).

Dakwah dengan demikian, tidak selalu dipahami sebagai ajakan terhadap pihak lain yang masih ingkar untuk mengikuti dan meyakini kebenaran ajaran Islam, tetapi juga merupakan ajakan "kedalam" sebagi suatu aktivitas instrospeksi secara pribadi, seraya menyebarkan kebaikan yang berasal dari nilai-nilai universal ajaran Islam kepada sesama umat Muslim. Sejak pada masa awal kemunculan Islam, dakwah merupakan salah satu aspek terpenting dalam agama dan masyarakat Muslim jelas memberikan apresiasi yang cukup tinggi terhadap seluruh aktivitas dakwah.

Oleh sebab itu, dakwah sebagai sebuah "misi kebenaran" yang diyakini sedemikian penting oleh setiap Muslim, menjadikan kegiatan ini hampir tak pernah mengalami masa surut, bahkan dalam beberapa hal justru tampak semakin meningkat dan fenomenal. Sekalipun Islam pernah mengalami degradasi politik dan seluruh wilayah kekuasaan Muslim terpecah-belah dan melemah, bahkan mungkin ada yang hancur dan runtuh, namun semangat dakwah tetap menyala dalam berbagai bentuk dan variasinya. Sejarah paling tidak mencatat, meredupnya kekuasaan politik Islam pada abad ke-11 hingga abad ke-13, justru di belahan dunia lainnya, Islam mengalami kejayaan gemilang secara spiritual, karena para misionaris Muslim sukses menyebarkan keyakinan 
mereka hingga jauh ke pedalaman Afrika, Tiongkok, India Timur, bahkan kemudian sampai ke wilayah Asia Tenggara (Arnold 2019, 15).

Penting juga dipahami, bahwa tema dakwah (a call to mission) seringkali muncul, terutama dalam bentuk khotbah atau artikulasi kebaktian tertentu yang ditujukan untuk mengajak atau mempengaruhi seseorang atau masyarakat tentang Islam. Padahal, sebuah "misi" tidak harus digambarkan secara ekslusif, hanya berorientasi kepada proses konversi non-Muslim (Riddell 2001, 308). Dakwah dalam cakupan lebih luas, bertujuan sebagai revitalisasi nilai moral-intelektual sekaligus re-dedikasi aspek religiusitas yang secara internal membentuk kesalehan primordial dan pada saat bersamaan, nilai-nilai Islam yang universal akan lebih dikenal secara lebih luas, karena aktivitas dakwah inheren dalam prilaku setiap Muslim. Dakwah pada masa-masa perkembangan Islam memang kental nuansa misionaristik, terutama melihat serangkaian penaklukan politik yang berjalan dalam suasana agresif. Semangat "misionaris" tentu saja muncul seiring "kewajiban suci” dari dalam diri setiap Muslim untuk menolak segala bentuk kekufuran dan pada saat yang sama mengajak mereka yang masih ingkar menerima ajaranajaran Islam. Prinsip-prinsip seperti toleransi, harmonisasi, dan moderasi, sesungguhnya melekat dalam artikulasi misi dakwah dan menjadi karakter dasar dakwah Islam sejak awal mula agama ini disebarkan.

Perubahan sosial yang sangat cepat dan peralihan struktur masyarakat yang semakin rumit, berpengaruh terhadap fleksibilitas dakwah Islam agar memiliki kemampuan menjawab berbagai tantangan zaman. Persentuhan Islam dengan beragam realitas budaya dan tradisi, memungkinkan aktivitas dakwah yang dijalankan berubah karakteristik dan bentuknya, terlebih aspek modernitas yang telah mengepung segala sisi kehidupan manusia. Dakwah, harus tetap teraktualisasikan dalam bentukbentuknya yang paling relevan dan tepat sasaran dengan mempertimbangkan aspek kebutuhan masyarakat. Perlu upaya revitalisasi dakwah yang tentu saja tidak harus berorientasi "misioner": menyebarkan kebenaran agama disertai meningkatnya upaya penarikan orang lain yang masih ingkar dan tidak akan puas sebelum agama tersebut merasuk ke dalam setiap jiwa manusia (Arnold 2019, 13).

Revitalisasi dakwah harus visioner dan mengandung semangat reformis, di mana upaya penyebaran nilai-nilai Islam dipandang sebagai "nilai kebaikan bersama" yang bertujuan membangun harmonisasi kehidupan manusia, dan disisi lain, semangat reformis ditunjukkan dalam upaya melihat entitas Islam sebagai "agama universal", sehingga selalu sesuai dengan segala perubahan zaman. Semangat inilah yang sebenarnya pernah mewujud ketika

pasukan Muslim justru sangat dihormati dan disegani ketika melakukan serangkaian penaklukan.

Pijakan dakwah secara "visionerprogresif" tidak larut dalam suasana romantisme, atau menganggap generasi awal Muslim adalah generasi paling ideal untuk kembali "dihidupkan" pada masa kini. Watak visioner tentu memandang DAKWAH, Vol.24, No.1, 2020 
masa depan sebagai suatu harapan sekaligus tantangan bagi artikulasi nilainilai Islam yang universal, bukan "kembali" ke masa lalu dengan mengadopsi keseluruhannya untuk dijadikan model pada era kekinian. Dakwah juga harus berwatak progresif, dengan tidak didorong oleh semangat "puritanistik" yang menggebu-gebu, seraya menempatkan segala entitas "kebaruan" apapun sebagai hal yang berubah atau menyimpang dari ajaran Islam yang paling otentik.

Semangat dakwah Islam yang berwatak "agresif-puritanistik" dalam banyak hal, pada akhirnya sekadar bentuk "romantisme keagamaan" yang memiliki citra "kolot" dan stagnan. Setiap misi dakwah tentu saja menyimpan energi kebaruan yang terus menerus memberikan dorongan perubahan secara dinamis dalam bentuk-bentuk artikulatif. Islam, tentu saja tidak hanya dipahami sebatas keyakinan, namun lebih dari itu, ia merupakan seperangkat nilai yang komprehensif sedemikian rupa, terbentuk dari jalinan tradisi-tradisi dan budaya, kemudian berpadu secara harmonis membentuk peradaban.

\section{Karakteristik Dakwah Islam:}

\section{Akulturasi, Asimilasi, dan Resepsi}

Dengan

istilah "Islamisasi" berarti terdapat aktivitas terus menerus dalam hal "konversi" dari non-Islam untuk "disesuaikan" atau "digantikan" dengan Islam. Proses Islamisasi di seluruh dunia merupakan suatu perjalanan panjang dari rangkaian aktivitas dakwah. Dengan demikian, dakwah dan Islamisasi dalam banyak hal identik, bahkan proses keduanya memiliki saling ketergantungan sehingga tidak mungkin terjadi Islamisasi tanpa aktivitas dakwah begitupun sebaliknya. Aktivitas dakwah bertujuan untuk "mengislamkan" seseorang atau sekelompok orang yang masih ingkar dengan cara mengajak untuk meyakini kebenaran ajaran-ajaran Islam. Menariknya, bahwa setiap proses Islamisasi yang terjadi di manapun, ketika bersentuhan dengan tradisi atau budaya lokal, hampir dipastikan tidak pernah mengikis habis ide-ide pra-Islam sampai ke akar-akarnya. Malah sebaliknya: di mana-mana ada sesuatu dari yang lama yang tetap tinggal, di mana disatu sisi tampak ide dan lembaga pra-Islam justru lebih banyak, tetapi di sisi lainnya mungkin ada yang "terIslamisasikan" secara sempurna (Drewes 1983, 323).

Bahkan sekalipun ketika Islam disebarkan di masa-masa paling awal, ide atau lembaga pra-Islam tidak tercerabut dari akarnya dan tetap menjadi bagian dari tradisi hidup yang pada akhirnya diadopsi kedalam ajaran Islam. Tradisitradisi tertentu dari Yahudi dan Kristen, ada yang tetap dipertahankan dan dikonversi kedalam Islam dan ada juga yang diganti atau dihapuskan. Semangat

misionaristik Islam, tidak serta merta memberangus ide-ide lama, tetapi lebih banyak mengkonversinya kepada hal yang lebih Islami. Barangkali disinilah fleksibilitas ajaran Islam yang memiliki kemampuan memoderasi tradisi atau ideide lama pra-Islam. Watak fleksibilitas agama ini kemudian menjadi karakter paling penting dari aktivitas dakwah yang dapat dilihat dari berbagai catatan sejarah. Paling tidak, dalam penggalan DAKWAH, Vol.24, No.1, 2020 
kronik Islamisasi di Nusantara, hampir dipastikan bahwa Arabisme yang seharusnya tampil lebih kuat justru tidak demikian. Kenyataannya, Islamisasi di Nusantara lebih menonjolkan aspek lokal, bahkan dalam banyak hal justru khas, hingga Kees Van Dijk sampai pada kesimpulan bahwa penyebaran Islam di Nusantara dilakukan oleh aktivitas dakwah yang "indigenous" secara kultur, berasal "dari dalam" bukan "dari luar" (Dijk 1998).

Sebagai agama dakwah (missionary), penyebaran Islam umumnya dibangun dalam suasana dialogis, sukarela, damai, dan hampir tanpa paksaan. Elan vital dakwah terdapat pada misinya yang humanis dan inklusif, sebagaimana ketika Nabi Muhammad mengutus para dai untuk menyebarkan agama Islam kepada sukusuku Arab yang masih kafir. Sikap dan kepribadian beliau dalam berdakwah benar-benar memberikan gambaran tentang misi kemanusiaan yang luas, bahkan begitu memahami kondisi bangsa Arab jahiliyah sehingga mendorong aktivitas dakwah disesuaikan dengan realitas dan kompleksitas masyarakatnya. Sifat misionaris Islam, hampir tidak pernah muncul dalam bentuknya yang memaksa atau mempertentangkan setiap tradisi-tradisi lama yang telah hidup dalam masyarakat. Kecuali bahwa semangat Islam yang disebarkan telah sedemikian telah mengancam status quo dan kedudukan politik para penguasa Arab. Mereka merasa khawatir dan terganggu dengan dakwah Islam yang menyuarakan kesetaraan sosial, humanisme, dan disisi lain, kritiknya yang sangat keras atas kebiasaan paganistik yang sebenarnya telah menyimpang jauh dari agama leluhur mereka.

Aktivitas dakwah sebagaimana yang dipraktikkan pada masa awal kelahiran Islam, berwatak inklusif di mana Islam diperkenalkan sebagai agama terbuka, sehingga sifat misionaristik dalam agama baru ini lebih menekankan kesadaran terus menerus akan "Kehadiran" Tuhan dalam masyarakat (theodicy), mengingat fanatisme terhadap kepercayaan kuno dalam tradisi Arab-pagan, telah menutup seluruh aspek kesalehan. Mereka justru semakin tenggelam dalam realitas "kebodohan" (jahili) yang tanpa disadari telah memupuk jiwa-jiwa hedonistik dan individualistik. Kehadiran Islam waktu itu, jelas membawa angin segar perubahan, terutama dalam konteks kesetaraan sosial, serta keberhasilannya dalam membangun suatu komunitas religius, inklusif, dan egalitarian yang diikat oleh semangat solidaritas berdasarkan iman.

Watak inklusif yang melekat dalam realitas dakwah sebagaimana masa awal, telah menginspirasi para sahabat Nabi dengan tetap mempertahankan

karakteristik dakwah yang inklusifegalitarianistik: Islam bukan agama "elitis"-dibanding Kristen-sehingga cukup menarik minat berbagai lapisan masyarakat. Semangat egalitarianisme dakwah semakin menarik kalangan bawah untuk bergabung dan ikut serta mengibarkan panji Islam. Lagi pula, beberapa invasi oleh pasukan Muslim ke beberapa wilayah lainnya di luar Hijaz, tidak semata-mata didorong oleh semangat suci agama, namun lebih banyak didorong oleh motif ekonomi- politik. Melalui penguasaan atas sumber- sumber keekonomian yang berasal dari wilayahDAKWAH, Vol.24, No.1, 2020 
wilayah taklukan, keberadaan bangsa Arab semakin diperhitungkan dalam percaturan politik dunia. Dalam beberapa hal kita dapat melihat, bahwa tersebarnya Islam ke seluruh penjuru dunia, terutama didorong oleh motif- motif keekonomian dan hal itu sangat wajar ketika ditemukan pula dalam konteks dakwah agamaagama misionaristik lainnya.

Sejak awal turunnya, penyebaran Islam lebih ditekankan pada upaya penyadaran manusia atas nilai-nilai monoteisme ditengah maraknya politeisme yang meluas. Fakta historis menyebutkan, bahwa ratusan berhala yang mengelilingi Ka'bah, menunjukkan betapa politeisme sangat kuat menguasai alam pikiran bangsa Arab. Perang terbuka atas kekufuran (paganisme) merupakan salah satu misi utama dari dakwah Islam yang digelorakan Nabi. Sekalipun terdapat pergeseran orientasi dakwah, setelah Nabi hijrah ke Madinah. Dakwah yang sebelumnya bercorak misionaristik-agresif berubah ke arah reformistik-progresif: aspek dialogiskultural dikedepankan oleh Nabi, terutama untuk lebih memperluas komunitas-komunitas Muslim.

Penyebaran Islam dalam periode Madinah, memperlihatkan aspek toleransi yang cukup tinggi, sebagaimana dibuktikan oleh beberapa utusan Nabi yang disebar ke berbagai suku Arab untuk mengajak mereka kedalam Islam, namun justru seringkali kandas. Semua ini menandakan karakter asli dari upaya dakwah beliau dan membuktikan tiadanya paksaan dalam dakwah (Arnold 2019, 70).

Menariknya, karakteristik dakwah Islam yang sekalipun tetap menyimpan semangat misionaristik, ia hanya sebatas menyampaikan kebenaran agama dan mengajak mereka yang masih kafir untuk beriman. Setelah Nabi memimpin suatu pasukan yang tangguh yang setia mengikutinya selama di Madinah, beliau mulai mengajak para suku Arab lainnya untuk bergabung dalam komunitas Muslim yang dipimpinnya. Penyebaran Islam diluar suku-suku Arab, dilakukan Nabi melalui surat yang dikirimkan kepada raja-raja besar dan penguasa lokal lainnya untuk memeluk agama Islam. Beberapa nama penguasa saat itu, seperti Kaisar Heraclius, Raja Persia, Gubernur Yaman, Gubernur Mesir, serta Raja Abyssinia termasuk dalam daftar penguasa yang paling awal mendapatkan seruan Nabi agar mengikuti agama Islam. Dalam surat yang ditulis, hampir merupakan ajakan tanpa paksaan sedikitpun, selain bahwa menyatakan ajaran Islam yang universal dan ajakan untuk menyembah kepada hanya satu

Tuhan. Dalam salah satu penggalan surat yang dibuat Nabi menyebutkan:

"...wahai rakyat yang bisa membaca tulisan, berimanlah pada suatu keyakinan yang sangat sesuai, baik buat kami maupun buat kalian. Inilah seruan kami, untuk menyembah hanya kepada Allah, serta tidak meminta selain kepadaNya. Karena itu, wahai rakyat yang bisa membaca tulisan, jika kalian menolak, maka berhati-hatilah. Kami adalah kaum Muslimin dan agama kami adalah Islam".

Semangat misionaristik memang tampak jelas terbaca dalam surat tersebut, sekalipun masih kurang tegas sebagai bentuk ajakan secara langsung untuk mengikuti agama Islam. Arnold menyebut bahwa surat yang ditujukan DAKWAH, Vol.24, No.1, 2020 
kepada para penguasa ini masih tampak kabur, namun pada akhirnya diantara beberapa memang ada yang secara sukarela menjadi Muslim, mengingat bahwa ajakan menyembah Tuhan Yang Satu dan beriman juga merupakan inti dari seluruh ajaran agama wahyu yang pernah ada (Arnold 2019, 60).

Nabi tampaknya ingin menegaskan dalam hal ini, bahwa Islam merupakan agama universal yang tidak terbatas hanya untuk kalangan bangsa Arab. Ide utama Islam sebagaimana diperkenalkan secara terus menerus tentu saja: satu Tuhan satu umat manusia. Ide monoteisme yang diperkenalkan Islam bukanlah suatu hal yang baru, sebab realitas historis membuktikan betapa tradisi pra-Arab yang dibawa oleh kepercayaan Yahudi-Kristen telah mengenal ide monoteistik ini sebelumnya. Fazlur Rahman tampaknya meragukan teori fermentasi religius ini yang menyebutkan telah adanya monoteisme yang samar-samar yang telah hidup sekian lama dalam ide bangsa Arab. Lebih jauh, Rahman beranggapan, bahwa apa yang diabstraksikan Nabi Muhammad mengenai ide-ide Islam yang ia peroleh dari wahyu Al-Qur'an (lihat, QS Yunus [10]:19 dan Al-Baqarah [2]: 213), tidaklah berhubungan sama sekali dengan kehidupan padang pasir kaum Badui (Rahman 2010, 3). Rahman justru mendasarkan tesisnya atas kenyataan bahwa wahyu yang pertama kali turun kepada Nabi, bukan membangun kesadaran monoteistik. Saya beranggapan, sekalipun wahyu yang pertama lebih menekankan kesadaran literasi, namun secara bersamaan membangun kesadaran koheren berupa "literasi-monoteistik" di mana Tuhan merupakan sumber segala pengetahuan.

Ide universal yang inheren dalam ajaran Islam tentang satu Tuhan dan satu umat manusia, tentu saja membawa dampak yang sangat berpengaruh terhadap seluruh karakteristik dakwah Islam. Sikap menghargai kelompok atau agama lainnya telah menjadi warna tersendiri bagi keberhasilan penyebaran ajaran Islam dan ide-ide moralreligiusnya melampaui wilayah-wilayah kesukuan Arab. Sangat tidak mungkin rasanya, Islam tersebar dengan begitu cepat, menyebarkan ide monoteisme dan nilai-nilai humanisme yang dikenal sampai keluar wilayah Jazirah Arab, jika tidak didasarkan atas semangat toleransi yang begitu tinggi. Bahkan dalam banyak hal, semangat toleransi yang ditunjukkan Nabi ketika memperkenalkan Islam setelah menaklukkan wilayah tertentu, telah memungkinkan mereka yang nonMuslim memilih, antara memeluk agama Islam atau membayar jizyah dengan tanpa memaksakan keyakinan kepada mereka. Lebih jauh, Arnold sampai pada kesimpulan bahwa toleransi menjadi watak utama dalam aktivitas dakwah Islam, menjadi sebuah tradisi yang telah terbangun mapan dan sulit sekali ditemukan bukti-bukti yang menyangkalnya (Arnold 2019, 100).

Hal yang tentu saja menarik dalam rangkaian historis misi Islam hingga tersebarnya agama ini, jelas karena karakteristiknya yang toleran dan seringkali berupaya menghindari konflik. Bagaimana tidak, beberapa wilayah "nonmuslim” yang pada waktu itu dibawah kekuasaan Bizantum atau Romawi, justru selalu mendapatkan sambutan hangat disaat pasukan Muslim menduduki wilayah mereka dan mengusir para 
“penjajah"di negerinya. Pasukan Muslim memberikan kebebasan dan kemerdekaan melaksanakan agama mereka dengan sedikit batasan yang ditentukan demi mencegah terjadinya friksi antara pengikut agama yang bersaing atau munculnya fanatisme melalui penonjolan simbol-simbol agama yang bisa menghina perasaan kaum muslimin (Arnold 2019, 100). Prinsip untuk selalu menghindari konflik dengan pihak lain, umumnya tertuang dalam berbagai kesepakatan yang mengikat secara politik. Sebuah kesepakatan yang dirumuskan pada saat Jerusalem menyerah dibawah kekuasaan Khalifah Umar bin Khatab, menarik untuk direnungkan:

"Dengan

menyebut nama

Tuhan yang Maha Pengasih lagi Maha Penyayang. Inilah jalinan keamanan yang diberikan Khalifah Umar bin Khatab, pelayan Tuhan, panglima kaum beriman untuk menanggung keamanan rakyat Elia. Ia menjamin keamanan semua pihak, baik yang sehat maupun yang sakit, menjamin keamanan hidup mereka, harta, gereja, dan jalan-jalan mereka, serta seluruh hal yang terkait dengan agama mereka. Gereja mereka tidak boleh dijadikan pemukiman dan tidak boleh dihancurkan...Demikian juga tidak boleh ada tekanan apapun dalam hal keyakinan yang boleh dipaksakan kepada mereka...” (Arnold 2019, 101)

Dengan asumsi kesepakatan diatas, paling tidak dapat dipahami bahwa penguasaan atas wilayah-wilayah tertentu oleh kekuatan politik Kristen, sedikit banyak telah membentuk iklim intoleransi, bahkan hal itu malah terjadi di kalangan internal Kristen sendiri. Keberadaan penguasa Bizantium yang menguasai kota-kota besar berpenduduk Kristen justru dalam banyak fakta lebih banyak mengekang kebebasan beragama diantara sesama penganut agama mereka sendiri. Michael the Elder, Patriarch Jacobite di Antioch pernah menulis pada akhir paruh abad ke-12:

"Inilah alasan Tuhan, Sang Maha Kuat, untuk membalas dendam dan mengubah kekaisaran yang besar sebagaimana yang Dia kehendaki, memberikan kekuasaan kepada mereka yang Dia kehendaki, dan mengangkat pihak lemah dari kejahatan bangsa Romawi dengan kekuatan yang telah menindas gereja-gereja dan biara-biara kami dengan kejam, menyiksa kami dengan tanpa belas kasihan. Tuhan telah mengirimkan para keturunan Ismail dari wilayah selatan untuk membebaskan kami dari cengkraman bangsa Romawi..." (Arnold 2019, 98)

Tidak saja dalam bentuk konteks sosial-politik, nilai-nilai toleransi dalam dakwah Islam secara inheren meresap kedalam aspek doktrinal dan teologis. Islam, mengakui seluruh nabi-nabi yang ada dalam tradisi Yahudi-Kristen, lengkap dengan seluruh kitab suci yang diturunkan Tuhan melalui tangan-tangan mereka. Bahkan, beberapa ritual kuno yang berasal dari tradisi kedua agama besar tersebut diadopsi sedemikian rupa sehingga menjadi bagian dari syariat Islam. Puasa dan haji, misalnya, memiliki keterkaitan erat dengan tradisi-tradisi pra Islam yang kemudian "di-Islamisasi" dengan tanpa membuang keseluruhan aspek nilai historisnya, kecuali beberapa ritualnya yang dianggap berlebihan. Kewajiban 
puasa Ramadan bagi umat Islam adalah pengganti dari puasa penebus dosa dalam tradisi Yahudi atau ritual ibadah haji yang diadopsi dari perjalanan spiritual Nabi Ibrahim dan istrinya Hajar, merupakan diantara ketetapan syariat Islam yang sebelumnya dipraktikkan oleh masyarakat Arab kuno. Toleransi dalam Islam dengan batas- batas tertentu telah menjadi suatu "praktik hidup" yang pada akhirnya melebur dalam model dan karakteristik dakwahnya yang dipraktikkan para misionaris Muslim selanjutnya.

Harmonisasi telah ditujukan melalui praktik dakwah Islam yang membangun dialektika dengan berbagai macam tradisi kultural. Ajaran-ajarannya yang mudah dan

fleksibel, memungkinkan agama ini diterima secara terbuka oleh kalangan masyarakat non-Arab. Melalui kelengkapan visi Islam yang universal, ia sepertinya telah menjamin bahwa agama ini dalam perkembangannya tidak akan betul-betul sama dari suatu tempat ke tempat yang lainnya atau dari suatu waktu ke waktu tertentu. Wilfred C Smith dalam "The Meaning and End of Religion" justru memandang bahwa pengertian yang sebenarnya dari sebuah "agama" merupakan sistem integral kepercayaan dan praktik yang dapat dipandang benar atau salah, adalah relatif baru dibanding dengan pengertian "agama" sebagai aspek dari kehidupan pribadi seseorang. Islam telah sejak awal penyebarannya menempatkan dirinya sebagai agama "non-elitis", di mana secara historis pandangan-pandangan hidup yang terkait dengannya membentuk sebuah tradisi kultural atau sebuah kompleks tradisi-tradisi; dan sebuah tradisi kultural dengan sendirinya tumbuh dan berubah; semakin demikian, semakin luas ruang lingkupnya (Hodgson 1999, 109-110). Para misionaris yang menyebarkan ajaran Islam ke luar wilayah Arab jelas menyadari hal ini, bahwa tradisi Islam bersifat transmitif, di mana ketika terdapat sesuatu "resep" yang sangat penting maka ia tetap dipertahankan, namun jika memang itu tak lagi diperlukan, "resep" itu dapat dimodifikasi atau diubah tanpa harus menanggalkan

"nilai-nilai" keagamaannya yang fundamental.

Harmonisasi secara kultural selalu terjadi di wilayah manapun Islam hadir, bahkan hampir-hampir tak ada suatu tradisi yang benar-benar tereliminasi atau hilang ketika agama ini diterima dan ajaran-ajarannya begitu hidup dalam suatu masyarakat. Indonesia merupakan contoh terbaik di mana harmonisasi kultural itu terjadi. Menariknya, agama misionaristik lainnya seperti Kristen justru lebih sulit diterima secara kultural karena mungkin sifat agama ini yang terkesan "elitis". Kenyataan bahwa para misionaris Kristen melalui semangat "gold, glory and gospel" yang seiring dengan menguatnya semangat ekspansionisme-kolonialisme justru dalam beberapa hal mengalami banyak kegagalan. Masa ini kemudian dikenal dalam kronologi sejarah Barat sebagai "the age of discovery" (Pires 2018, xiii) atau abad penemuan dunia baru, di mana pada periode ini banyak sekali bangsa di Eropa Barat melakukan penjelajahan dunia dengan berlayar dengan motif kompetisi untuk menunjukkan keunggulan-keunggulan mereka atas ilmu pengetahuan dan teknologi, seiring motif keekonomian untuk menguasai wilayahDAKWAH, Vol.24, No.1, 2020 
wilayah yang melimpah sumber daya alamnya untuk dieksploitasi dan dipergunakan sepenuhnya bagi kepentingan Dunia Barat.

Toleransi dan harmonisasi menjadi ciri penting dalam aspek dakwah Islam, bahkan memiliki akar sejarahnya sejak awal mula berkembangnya agama ini di wilayah aslinya, jazirah Arab. Prinsip keduanya juga secara implisit ditunjukkan dalam salah satu hadis, "sesungguhnya agama yang paling diridai Allah adalah yang cenderung kepada kebenaran (al-hanifiyah) dan toleransi (al-samhah)". Istilah "hanif" seringkali ditujukan pada ide monoteistik awal yang diperkenalkan Nabi Ibrahim as, sehingga ketika Nabi Muhammad menyatakan dirinya sebagai pengikut ajaran "hanif" Ibrahim, berarti secara tidak langsung beliau menyandarkan genealogi keagamaannya secara lurus (aldin al-qayyim). Tidak hanya itu, Fazlur Rahman lebih jauh berkesimpulan bahwa garis genealogi ajaran monoteisme yang berasal dari Nabi Ibrahim, melalui para nabi terdahulu, hingga sampai kepada Nabi Muhammad saw, merupakan matarantai yang lurus tanpa penyimpangan. Adapun ide monoteistik terdahulu-yang diadopsi para ahli Kitab-tampaknya tidak mampu menjaga garis yang lurus ini, jika tidak, tidak mungkin terjadi perselisihan sektarian yang mengganggu toleransi dan harmonisasi (Rahman 2017, 211).

Namun demikian, patut disayangkan bahwa citra Islam sebagai agama toleran dan harmonis justru seringkali dipersepsikan sebaliknya. Beberapa sarjana Barat yang tendensius dalam meneliti sejarah Islam, kerap menuduh bahwa dakwah Islam senantiasa didahului dengan cara-cara kekerasan. Padahal, kita sepatutnya mencari bukti-bukti yang paling esensial mengenai dakwah Islam secara lebih mendalam lagi, daripada sekadar mengeksploitasinya untuk menghapus tokoh-tokoh mitos yang menggambarkan pejuang-pejuang Muslim dengan

membawa pedang di tangan kanan sedangkan Al-Qur'an di tangan kirinya (Arnold 2019, 19). Umumnya, para sarjana Barat ini menyandarkan pendapatnya-jika bukan didasari atas prasangka piciknya-atas apa yang disimpulkan Ignaz Goldziher pada periode Nabi di Madinah, setelah struktur masyarakat Muslim mulai terbentuk, di mana kompleksitas persoalan agama dan sosial-politik merupakan saat (situasi) bertahan dan melancarkan serangan dengan kata-kata dan dengan pedang (Goldziher 1991, 9).

Periode Madinah merupakan satu periode penting di mana penyebaran agama Islam secara definitif tersealisasikan. Posisi Nabi Muhammad pada waktu itu tidak saja sebatas pemimpin agama, tetapi melekat dalam dirinya seorang pemimpin politik bahkan "kepala negara". Hal yang sangat wajar di wilayah manapun bila seorang pemimpin politik memiliki tanggung jawab penuh atas keamanan wilayah yang dipimpinnya, terlebih jika berada dalam ancamanancaman politik. Sebagai seorang kepala negara, beliau akan mengatur strategi untuk bertahan dari serangan atau ancaman musuh dan pada saat yang bersamaan mungkin saja melakukan penyerangan demi menjaga wilayahnya. Selama satu dasawarsa di Madinah, Nabi tetap menjaga harmonisasi dengan agamaagama lain, terutama Yahudi-Kristen DAKWAH, Vol.24, No.1, 2020 
dengan masih mengarahkan kiblat umat Muslim ke Yerusalem. Konsekuensi perubahan arah kiblat Muslim, sematamata merupakan titik balik atas revitalisasi genealogi kenabian Ibrahim, di mana Ka'bah merupakan simbol yang paling dihormati oleh seluruh entitas agama apapun dengan merujuk kepada ide monoteistik Ibrahim. Meskipun perpindahan arah kiblat ini banyak disalahpahami oleh kalangan orientalis sebagai perceraian Islam dengan Yahudi, Rahman membantah seluruh asumsi tersebut, dengan mendasarkan atas fakta historis bahwa terdapat seorang pemimpin besar kelompok Yahudi di Madinah bernama Bara ibn Ma'rur yang justru telah lebih dulu menolak berkiblat ke Yerusalem dan ia lebih memilih Ka'bah sebagai kiblatnya ketika itu (Rahman 2017, 216).

Watak toleransi yang hidup dalam tradisi Islam, semakin membawa tersebarnya agama ini meluas melewati batas-batas jazirah Arab. Sebuah agama berwatak intoleran, tentu saja akan sulit berkembang, bahkan dipastikan memperoleh serangkaian penolakan dari masyarakat, ketika mereka dipaksa untuk mengikuti satu kepercayaan tertentu yang dianggap asing. Pasca wafatnya Nabi Muhammad, Islam terus berekspansi ditengah kesibukan khalifah Abu Bakar sebagai pemimpin baru komunitas Muslim menghalau para pemberontak dalam perang Riddah, yaitu perang terhadap "orang-orang murtad" (apostasy). Hanya dalam jangka kurang dari dua tahun, kekuatan umat Islam yang telah disusun sedemikian rupa, jauh tersebar dibandingkan pada masa hidup Nabi Muhammad (Hodgson 1999, 284). Sekalipun dakwah Islam diiringi serangkaian penaklukan, namun tetap dipastikan bahwa masyarakat dalam wilayah taklukan Islam tidak pernah "dipaksa" untuk menjadi Muslim. Tidak ada usaha untuk mengalihkan agama orang-orang di wilayah kekaisaran, yang secara praktis semua telah memeluk bentuk-bentuk agama konvensional (Hodgson 1999, 286). Lagi pula, motivasi pasukan Muslim melakukan ekspansi, tidak seluruhnya berorientasi keagamaan, namun lebih banyak didasari motif lainnya yang lebih ekonomis yang dalam banyak hal, telah mendorong kebangkitan solidaritas moral dan finansial.

\section{Islamisasi di Nusantara: Rasionali- sasi Dakwah dan Agama "Indigenous"}

Terdapat banyak teori yang menjelaskan periodesasi Islamisasi di Nusantara yang hampir sulit memilih diantara sekian teori yang paling mungkin diterima dan dapat menggambarkan secara tepat proses konversi masyarakat Muslim. Penjelasan mengenai Islamisasi di Nusantara, kebanyakan diperoleh dari data-data yang berasal dari catatan perjalanan orang-orang Eropa. Tidak banyak data- data yang berasal "dari dalam” yang langsung ditulis oleh sarjana lokal, kecuali beberapa catatan historis yang kebanyakan diadopsi dari beberapa literatur klasik Jawa yang kemudian direkonstruksi secara lebih modern. Dalam pandangan sarjana Barat, historiografi Islam di Nusantara terkadang mengabaikan data-data tertentu yang dianggap sarat unsur mistik atau dongengdongeng yang dituturkan dalam tradisi 
masyarakat lokal. Namun hampir dipastikan, sangat mustahil jika kronik penyebaran Islam di Nusantara tanpa melibatkan naskah-naskah lama yang ditulis "dari dalam" pada masa peralihan kerajaan Hindu-Budha kepada Kesultanan Muslim.

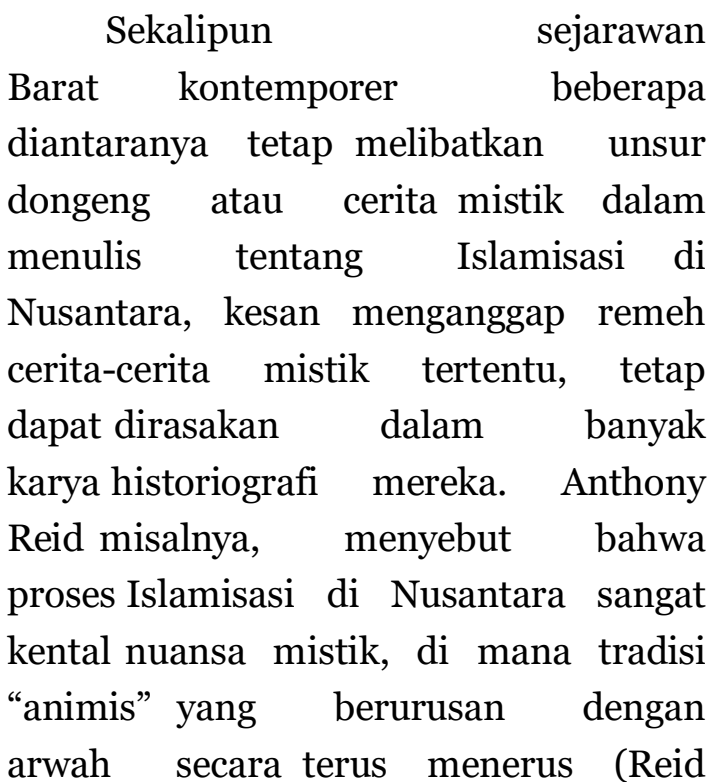
2004, 23-29) tetap bertahan di tengah proses Islamisasi. Disisi lain, Michael Laffan misalnya, memulai historiografinya dengan mengambil tema sufistik yang mengadopsi karya al-Yafi'i yang mencatat kehidupan tokoh sufi besar asal Baghdad, Syekh Abdul Qadir al-Jilani (1077-1166) yang kebetulan namanya dihubungkan dengan kelompok tarekat Qadiriyah yang pengikutnya cukup banyak di Indonesia. Laffan mendukung teori A.H. Johns yang menyebut terdapat hubungan antara perdagangan dan penyebaran Islam ke Nusantara di tangan syekh Tarekat (Laffan 2015, 5).

Proses Islamisasi di Nusantara akan tampak lebih unik dan sangat berbeda dengan model ekspansi Islam yang dijalankan melalui serangkaian penaklukan. Keunikan historiografinya, hampir keseluruhan selalu tampak "dari dalam" memuat rencana sang Maha Agung kepada manusia dalam menegakkan kebenaran-Nya. Para penulis Muslim selalu mencatat aspekaspek ilahiyah ini dalam melihat keberhasilan Islamisasi Nusantara, termasuk bagaimana mereka memberikan penghormatan kepada para misionaris (wali) Islam yang memiliki kekuatan mistik yang setara dengan mukjizat sebagaimana diwariskan Tuhan kepada para nabi-Nya. Reid mencatat, kronik-kronik ini tidak ragu menggambarkan kekuasaan para penguasa dan asal-usul negara dengan menggunakan konsep kekuatan magis (kesaktian) yang berasal dari masa praIslam, namun tampak jelas deskripsi proses Islamisasi dijaga agar tetap berada dalam batas-batas yang dapat diterima oleh kalangan Muslim di sebagian besar dunia (Reid 2004, 21).

Kita tentu saja sepakat, bahwa Islamisasi di Nusantara terjadi melalui jaringan perdagangan yang telah dimulai sejak awal abad ke-14-bahkan mungkin sebelumnya. Jalur-jalur pesisir pantai di wilayah Nusantara merupakan pelabuhan-pelabuhan ramai di mana hampir tidak pernah sepi oleh pemandangan kapal-kapal besar yang bersandar dan melakukan transaksi perdagangan dengan warga lokal. Arnold memulai catatan historisnya tentang Islamisasi Nusantara yang dimulai dari kawasan Sumatera (Pasai), sekalipun ia sendiri merasa pesimis soal ketepatan waktunya sejak kapan konversi Islam di wilayah Hindia Timur ini terjadi. "Menentukan tanggal kapan pertama kalinya Islam diperkenalkan di kepulauan Melayu adalah pekerjaan mustahil bisa 
dilakukan dengan benar. Bisa jadi, Islam telah menyebar disana melalui para pedagang Arab pada awal-awal abad Hijriah..." (Arnold 2019, 505). Barangkali karena berbagai catatan tentang sejarah Nusantara (terutama hikayat-hikayat, serat, atau suluk) baru ditulis abad ke-15 atau ke-16, maka sangat masuk akal jika sulit untuk menentukan sejak kapan wilayah kepulauan Melayu-terutama Nusantara-ini telah mengenal Islam. Namun paling tidak, laporan Arnold menyebutkan bahwa pada pertengahan abad ke-14, seorang penjelajah Muslim terkenal, Ibnu Batutah mengunjungi kepulauan Melayu dan mendapatkan bahwa sultan Muslim di Samudera Pasai telah menjalin hubungan yang baik dengan penguasa Delhi (Arnold 2019, 507). Laporan ini dapat membawa kita pada suatu asumsi, bahwa Islam telah hadir di Nusantara sebelum abad ke-14 dan hal ini tentu saja dapat mendukung tesis Arnold yang menyebut dakwah Islam telah sampai ke Nusantara sejak awal abad pertama Hijriah.

Bagi sebagian besar pengamat, mengabaikan aspek mistis mengenai peran tokoh-tokoh suci legendaris penyebar Islam (Wali Sanga) atau dimensi magis lainnya yang menyatu dan hidup dalam tradisi masyarakat Nusantara, jelas akan sulit merekonstruksi bagaimana aktivitas dakwah Islam dapat dengan mudah masuk seraya diterima oleh mereka. Menarik untuk dilihat dalam konteks Islamisasi ini, bahwa metode dakwah yang dijalankan para penyebar Islam justru lebih diterima dan secara sadar, sebab telah terjadi asimilisi dan akulturasi ajaran Islam dengan budaya lokal. Padahal, upaya Kristenisasi mungkin saja telah lebih dulu terjadi,

mengingat kurun niaga (age of commerce) sebagai bagian dari kegiatan ekspansionisme dan kapitalisme bangsabangsa Eropa terhadap wilayah Asia telah berjalan sejak pertengahan abad ke-15, sedangkan Islamisasi di Nusantara puncaknya dimulai abad ke-16 dan 17. Para misionaris Muslim yang dikenal dengan para wali seringkali diasosiasikan sebagai mistikus-sufi dan diyakini mempunyai kekuatan supranatural. Namun, ketertarikan seseorang terhadap Islam, bukan karena aspek mistik para penyebarnya, tetapi justru aspek lain yang secara psikologis banyak orang yang sedang mencari agama baru atau secara teologis, sedang berupaya merasionalisasi keberagamaan mereka. Dalam psikologi konversi, Islamisasi bukan sebatas peralihan agama secara teknis, namun mencakup perubahan mental yang sangat dalam, tidak hanya perubahan satu agama ke agama lain, tetapi juga sebagai perubahan sikap di dalam suatu agama (Steenbrink 1984, 80).

Barangkali, masih menyisakan banyak sekali pertanyaan dikalangan pengamat soal apa penyebab orang Nusantara bersedia menganut Islam. Pertanyaan yang barangkali dapat ditemukan jawabannya secara berbedabeda tergantung kepada wilayah mana di Nusantara yang akan kita amati. Saya melihat, konversi Islam yang terjadi dalam masyarakat Nusantara merupakan pengaruh secara langsung dari karakteristik dakwah yang dikemas sedemikian lupa oleh para penyebarnya. Islam sebagai agama yang sangat rasional dalam menjawab segala persoalan yang terjadi dalam masyarakat yang tidak 
ditemukan dalam agama sebelumnya yang mereka kenal, merupakan titik pijak utama untuk melangkah lebih jauh pada prosesproses konversi ke dalam agama Islam. Persoalan-persoalan masyarakat yang dapat diselesaikan secara "Islam" oleh para misionaris Muslim-dalam beberapa kasus terkadang bukan misionaris tetapi orang tertentu yang mengerti Islam-beriring jalannya waktu mempermudah proses konversi agama tersebut. Steenbrink menyebut bahwa konversi agama Islam ada yang dilakukan secara individual dan kolektif atas dasar kemauan dan kesadaran sendiri, ikhlas, dan tanpa paksaan (Steenbrink 1984, 80). Terdapat keunikan pada karakteristik dakwah Islam di Nusantara yang dengan mudah dan hampir tanpa pertentangan sedikitpun, diterima dalam suasana perbedaan adat dan tradisi lokal yang sangat beragam.

Karakteristik dakwah Islam di Nusantara yang dapat ditemukan dalam beberapa karya sastra lokal sangat menekankan aspek sufistik, seperti penggambaran A.H. Johns dan Fatimi yang tampak lebih memandang serius bukti-bukti "dari dalam" dan membangun soal penjelasan tandingan perihal proses Islamisasi yang berpusat pada imam- imam sufi yang cakap dalam ilmu kebatinan dan memiliki kekuatan penyembuh, dan tidak kalah penting...bersedia menggunakan istilah dan unsur-unsur kebudayaan pra-Islam dalam suatu semangat islami (Reid 2004, 23). Sumber-sumber mengenai proses Islamisasi di Nusantara yang bercorak sufistik memang diakui oleh kebanyakan sejarawan, bahkan dalam banyak hal,tradisi Jawa sangat mendominasi aktivitas konversi masyarakat Indonesia ke dalam agama Islam. Paling tidak, nama-nama manuskrip Jawa seperti Serat Kandaning Ringgit Purwa dan Babad Tanah Jawi, menceritakan kronologi Islamisasi Jawa yang dikaitkan dengan runtuhnya kerajaan-kerajaan HinduBudha dan digantikan oleh kerajaan Islam. Sebagaimana catatan J.J Ras, Serat Kanda menjelaskan silsilah para penyebar Islam di tanah Jawa yang memiliki hubungan erat dengan para raja Brawijaya. Para leluhur bangsawan Jawa jelas terkait dengan genealogi aristorkasi ini dan disisi lain, terdapat cerita mengenai para aristokrat "rohani" yang merupakan kemenakan Brawijaya dari Cempa, yaitu Sayyid Raden Rahmat atau Sunan Ngampel yang kemudian menyebarkan jaringan dakwahnya melalui orang-orang yang dipekerjakannya (Ras 1990, 128).

Dalam beberapa historiografi Barat, Islamisasi di Nusantara umumnya dibedakan kedalam tiga periode: prakolonial, kolonial, dan pasca-kolonial yang membedakan dari historiografi para sarjana "insider" Indonesia yang secara garis besar membedakannya ke dalam dua periodisasi, di mana pada periode pertama terdapat tradisi intelektual sebelum bersentuhan dengan pahampaham pembaharuan Jamaluddin alAfghani, Muhammad Abduh, Iqbal dan lain-lain. Sedangkan periode kedua adalah tradisi intelektual Islam setelah bersentuhan dengan ide-ide modernisme tersebut (Riddell 2001, 3). Dengan merujuk pada pola historiografi "insider", 
Islamisasi di Nusantara jelas memiliki asal-usul sejarah dengan pendekatan cerita sebagaimana yang terdapat dalam beberapa manuskrip yang ditulis oleh beberapa tokoh mistikus Muslim atau beberapa karya tulis yang berasal dari kalangan istana yang juga memiliki ciri khas yang kurang lebih sama, bersifat historiografi-mistis. Namun demikian, sulit rasanya untuk tidak menemukan historiografi Islam di Nusantara, kecuali yang ditulis setelah abad ke-15 dan 16 . Kesusasteraan Nusantara tampaknya mulai berkembang di abad-abad ini, sehingga pengungkapan proses Islamisasi kebanyakan memang dapat merujuk pada karya-karya sastra dalam kurun yang disebutkan.
Islamisasi

Tenggara- khususnya kurun abad ke-15, namun sudah ada orang Islam di wilayah ini sejak abad ke-7 sebagaimana telah ditemukan jalinan perdagangan antara Arab dan Sri Lanka, sehingga pada abad ke-8 para pedagang Arab banyak di temukan di Kota Canton (Arnold 2019, 506). Persebaran para pedagang Arab ini seiring dengan datangnya bangsa Portugis ke wilayah Asia Tenggara dan kemungkinan besar teori yang mengatakan bahwa Islamisasi Nusantara melalui jalur perdagangan tentu sangat sulit terbantahkan. Barangkali, bahwa terdapat pendapat lain yang menyebutkan

Islamisasi di Nusantara erat kaitannya dengan para pedagang dari Gujarat, sejauh ini belum dapat dibuktikan secara faktual. Sebab, pada kurun Islamisasi Nusantara, Gujarat tentu saja bukan merupakan wilayah kekuasaan politik Islam. Namun, mengingat bahwa penyebaran Islam yang paling awal dimulai dari Campa pada abad ke-14 dan posisi Campa lebih dekat dengan Tiongkok, kemungkinan bahwa para pedagang Arab yang banyak ditemukan di Canton juga berjasa dalam proses Islamisasi. Tidak menutup kemungkinan, para pedagang Cina Muslim juga ikut berperan sebagai dai yang mengislamkan Nusantara melalui aktivitas perdagangan.

Itulah sebabnya, Islamisasi di Nusantara memang sangat berbeda dengan model Islamisasi di Timur Tengah yang cenderung misionaristik. Aktivitas dakwah yang dilakukan dengan cara perdagangan tentu akan lebih memberikan warna tersendiri, paling tidak, agama Islam yang seringkali dipersepsikan pengamat Eropa sebagai agama yang dianut oleh "orang-orang Moor” yang "tidak beradab”, jelas bertolak belakang. Para pedagang jelas merupakan orang-orang yang "tercerahkan", sehingga jika mereka memang mengemban misi dakwah untuk menyebarkan ajaran Islam, maka Islam yang terbentuk di Nusantara jelas lebih beradab. Hubungan antara aktivitas perdagangan dengan para syekh pemimpin tarekat Sufi, memungkinkan telah memberi corak tersendiri dalam aktivitas dakwah yang dijalankan. Keterjalinan ini selanjutnya menunjukkan bahwa dakwah atau proses Islamisasi secara keseluruhan dapat dilihat kedalam tiga tujuan yang saling beriringan: pertama merekrut pengikut baru (proselytizing), kedua mengganti atau menyesuaikan adat sesuai syariat, dan ketiga ajakan secara ketat mengikuti 
syariat (Soenarto 2005).

Hampir dipastikan, bahwa perjalanan panjang proses Islamisasi di Nusantara memiliki karakteristik dasar sebagai dakwah dengan pendekatan kultural, di mana proses akulturasi dan asimilasi kemudian secara alami membentuk semacam "indigenous" kultur yang melekat dalam konteks keislaman masyarakat Indonesia. Masyarakat Nusantara memiliki kemampuan yang luar biasa dalam menerima atau menolak nilai dan budaya yang berasal dari luar.

Ketika modernisasi memasuk wilayah Nusantara, simbol-simbol yang berasal dari luar memang dapat diterima sebagai suatu "budaya baru" namun Indonesia sampai saat ini tidak pernah terdampak "Westernisasi" secara total. Budaya asing itu hanyalah sebatas imitasi kultural dan dalam batas-batas tertentu bersifat simbolik, tak pernah dapat mengubah keseluruhan karakteristik dasar dan watak bangsa Indonesia yang religius dan "tradisional". Uniknya, penerimaan atas budaya asing yang sedemikian luas, justru telah membangkitkan semangat kembali kepada budaya sendiri, sama halnya ketika Islamisasi terjadi yang berkonfrontasi langsung dengan tradisi Hindu-Budha, maka yang terjadi malah "re-jawanisasi" (Dijk 1998, 5): sebuah "kesadaran kultural" untuk mempertegas kembali jati diri mereka sebagai orang Jawa, tidak kembali kepada kepercayaan Hindu-Budha maupun model Islam Arab. Revitalisasi dakwah Islam di Nusantara yang sukses melakukan konversi agama dari non-Muslim kepada Islam, telah menjadikan bentuk Islam di Nusantara-bahkan dalam beberapa hal juga di Asia Tenggara-lebih khas, mengakar, dan "indigenous" yang tidak sama dengan corak Islam di manapun. Menariknya, bahwa para misionaris Muslim yang dikenal dalam berbagai catatan sejarah berdasarkan cerita, bahwa para wali (the nine saints) yang kerapkali dianggap mitos dalam ceritacerita Jawa masa lalu, justru belakangan semakin diperhitungkan sebagai "pahlawan" dakwah dan metode dakwah mereka dalam mengislamkan Nusantara dipandang telah berhasil membentuk Islam yang lebih rasional, modern, dan legalistik, dibanding bahwa mereka telah meninggalkan jejak historis Islam yang tradisional, penuh takhayul, atau tipetipe sufi-mistik yang kehilangan nalar rasionalitasnya (Soenarto 2005, 34). Nusantara telah mengalami sebuah peradaban yang tinggi, yang tercermin dari budaya literer dan religiusitasnya yang canggih bahkan jauh sebelum Islam ini hadir (Ricklefs 2013, 29). Dengan demikian, para misionaris Muslim merupakan orang-orang yang sangat memahami peradaban, para sufiintelektual yang mampu memadukan secara harmonis antara nalar modern dan tradisi spiritual. Penyatuan dua entitas ini bukan menjadikan Islam di Nusantara sebagai agama sinkretis tetapi justru sebagai agama rasional yang memiliki kedalaman etis.

Ikatan-ikatan solidaritas

keagamaan yang begitu kuat membentuk karakteristik masyarakat Indonesia, merupakan akibat langsung dari proses Islamisasi dan aktivitas dakwah yang terjalin dalam suasana kultural, melalui ajakan kepada Islam secara rasional. Sangat tidak mungkin rasanya, jika terdapat anggapan bahwa Islamisasi melalui dakwah di Nusantara dilakukan 
para mistikus yang cenderung mementingkan aspek kesalehan pribadi atau seorang pertapa yang cenderung menjauhi hiruk-pikuk kehidupan dunia. Islamisasi jelas mengandaikan segala hal yang rasional dan terukur, sehingga ketertarikan terhadap Islam, karena didorong oleh kepercayaan mereka yang sebelumnya irasional dan memilih Islam karena ajarannya lebih rasional. Perlu juga dilihat, bahwa proses Islamisasi melibatkan berbagai hal, terkait langsung dengan konteks sosial-budaya, ekonomi, atau politik, sehingga aktivitas dakwah harus menghitung secara tepat apa saja yang sangat dibutuhkan masyarakat. Sekalipun dakwah dan proses Islamisasi di Nusantara dilakukan dengan pendekatan kultural, namun dalam beberapa hal pendekatan ekonomi-politik patut diperhitungkan, di mana para dai atau para wali adalah mereka yang memiliki kedudukan istimewa ditengah masyarakat. Para penyebar Islam juga memanfaatkan aspek politik, terutama bagaimana "genealogi politik" sangat strategis untuk meningkatkan citra kharismatiknya sebagai sosok yang memiliki matarantai keturunan dengan para raja atau penguasa di masa lalu.

Perlu juga dipahami, bahwa Islamisasi yang terjadi di seluruh kawasan Kepulauan Nusantara, jika merujuk masa perkembangan intelektual Islam yang belum bersentuhan dengan modernisasi, aktivitas dakwah pada masatersebut jelas belum tersistematisasi dalam struktur organisasi yang jelas. Para misionaris Muslim sangat menyadari konteks rasionalitas dakwah dengan memanfaatkan suasana kultural masyarakat untuk membangkitkan kesadaran religius secara terus menerus. Islam diperkenalkan sebagai entitas rasional yang dapat menjawab berbagai persoalan masyarakat, tidak hanya sebatas kemampuan ajaran-ajarannya yang fleksibel lalu berasimilasi dengan kebudayaan setempat.

\section{Kesimpulan}

Rasionalisasi dakwah Islam terletak pada karakteristiknya yang hampir tidak pernah berubah, bahwa toleransi dan moderasi terutama inheren dalam ajaranajarannya yang luhur. Sejak Islam dilahirkan ditengah realitas keterbelakangan bangsa Arab, kemampuan toleransinya yang sangat mengagumkan, membuat proses Islamisasi terjadi sangat cepat. Peradaban Islam jelas terbangun atas jalinan tradisi intelektual yang berpadu secara harmonis dengan aspek-aspek kebudayaan manusia. Tanpa harus mengikis habis ide-ide praIslam yang telah hidup menjadi warisan sejarah dalam tradisi masyarakat, Islamisasi berjalan melalui beragam aktivitas dakwah dengan metodenya masing- masing. Para misionaris Muslim sejauh ini dapat disebut tokoh intelektual yang cerdas dalam mengemas berbagai pendekatan metodologis, menyebarkan ide-ide Islam secara rasional sehingga hampir dipastikan tidak mempertentangkan aspek-aspek perbedaan tradisi dan budaya yang telah menjadi praktik hidup dalam suatu masyarakat. Islam sebagai agama misionaristik berkembang dalam suasana etika-religius yang toleran dan humanis yang sesuai dengan kebutuhan-kebutuhan spiritual kehidupan manusia.

Aktivitas dakwah dan Islamisasi tentu saja memiliki warna dan coraknya 
tersendiri disesuaikan dengan realitas historis suatu masyarakat. Semangat misionaristik-agresif di masa-masa awal, ditunjukkan oleh serangkaian upaya penaklukan sebagai bagian dari upaya penguatan kekuasaan politik. Pergeseran dan perubahan realitas sosial tentu saja mempengaruhi pola Islamisasi yang dijalankan para misionaris Muslim dengan citra dan kekhasan tersendiri yang tidak mungkin sama, mengingat bahwa di setiap wilayah memiliki tradisi sosial yang berbeda-beda. Revitalisasi dakwah menjadi penting dengan tidak membangkitkan semangat romantisme seraya mempertegas konsep ideal masyarakat masa lalu yang dibangun pada masa awal perkembangan Islam. Revitalisasi dakwah jelas mempertimbangkan aspek-aspek

perubahan sosial sehingga semangat misionaristik-agresif sebagaimana periodesasi penaklukan atau menghidupkan kembali romantisme Islam seharusnya dipandang tidak lagi relevan. Revitalisasi dakwah harus visioner, melihat jauh ke depan dan ikut serta dalam mempengaruhi setiap perubahan sosial. Kecenderungan reformis-progresif dalam dakwah Islam akan menjaga keotentikan ajaran Islam yang rasional, humanis, dan relevan dengan segala perubahan zaman. 


\section{Daftar Pustaka}

Armstrong, Karen. Islam: A Short History. Yogyakarta: Ikon Teralitera, 2002.

Arnold, Thomas W. Sejarah Lengkap Penyebaran Islam di Dunia. Yogyakarta: Ircisod, 2019.

Dijk, Kees Van. "Dakwah and Indigenous Culture: The Dissemination of Islam." Bijdragen tot de Taal Lan En Volkenkunde, 1998: 218-235.

Drewes, G.W.J. "Indonesia: Mistisisme dan Aktivisme." In Islam Kesatuan dalam Keragaman, by Gustave E von Grunebaum, 327. Jakarta: Yayasan Obor, 1983.

Goldziher, Ignaz. Pengantar Teologi dan Hukum Islam. Translated by Andras and Ruth Hamori. Jakarta: INIS, 1991.

Hodgson, Marshall G.S. The Venture of Islam: Iman dan Sejarah dalam Peradaban Dunia. Jakarta: Paramadina, 1999.

Laffan, Michael. Sejarah Islam di Nusantara. Yogyakarta: Bentang, 2015. Meuleman, Johan. "Dakwah, Competition for Authority, and Development."
Bijdragen toot the Taal Land en Volkekunde, 2011: 236.

Pires, Tome. Suma Oriental. Translated by Adrian Perkasa and Anggita Pramesti. Yogyakarta: Penerbit Ombak, 2018.

Rahman, Fazlur. Islam. Bandung: Penerbit Pustaka, 2010.

- Tema-Tema Pokok Al-Qur'an. Translated by Ervan Nurtawab and Ahmad Baiquni. Bandung: Mizan, 2017.

Ras, J.J. "Tradisi Jawa Mengenai Masuknya Islam di Indonesia." In Beberapa Kajian Indonesia dan Islam, by W.A.L Stokhof and N.J.G Kaptein, 128. Jakarta: Inis, 1990.

Reid, Anthony. Sejarah Modern Awal Asia Tenggara: Sebuah Pemetaan. Jakarta: LP3ES, 2004.

Ricklefs, M.C. Mengislamkan Jawa: Sejarah Islamisasi di Jawa dan Penentangnya dari 1930 Sampai Sekarang. Jakarta: Serambi, 2013.

Riddell, Peter G. Islam and The MalayIndonesian World: Transmission and Responses. London: Hurst \& Company, 2001.

Soenarto, Ermita. "From Saints to Superheroes: The Walisongo Myth in Contemporary Indonesia's Popular Genres." Journal of The Malaysian Branches of The Royal Asiatic Society, 2005: 289.

Steenbrink, Karel A. Beberapa Aspek Tentang Islam di Indonesia Abad ke-19. Jakarta: Bulan Bintang, 1984. 